\title{
Empowerment of the Bidayuh Rural Community Oil Palm Smallholders: A Case Study in Serian District, Sarawak, Malaysia
}

\author{
Novel Lyndon ${ }^{1}$ \\ Nurmahfuzah Razak² \\ Azima A.M. ${ }^{3}$ \\ Junaidi A.B. ${ }^{4}$ \\ Sivapalan S. ${ }^{5}$ \\ ${ }^{1}$ Associate Professor, Faculty of Social Sciences and Humanities, Universiti Kebangsaan Malaysia \\ novel@ukm.edu.my \\ ${ }^{2}$ Graduate Research Assistant, Faculty of Social Sciences and Humanities, Universiti Kebangsaan Malaysia \\ ezzah_fuzz@yahoo.com.my \\ ${ }^{2}$ Associate Professor, Faculty of Social Sciences and Humanities, Universiti Kebangsaan Malaysia \\ azima@ukm.edu.my \\ ${ }^{4}$ Senior Lecturer, Faculty of Social Sciences and Humanities, Universiti Kebangsaan Malaysia \\ jab@ukm.edu.my \\ ${ }^{5}$ Associate Professor, Faculty of Social Sciences and Humanities, Universiti Kebangsaan Malaysia \\ sivap02@gmail.com
}

\section{Doi:10.5901/mjss.2015.v6n4s3p55}

\section{Abstract}

Empowerment exists and naturalized into the human self as an impetus to improve themselves through potential, power growth and authority. The success of empowerment will improve the competitiveness and reduce the level of dependency of the communities and individuals towards the government and the country. Therefore, the main objective of this study was to examine the role of MPOB (Malaysian Palm Oil Board) as the agency responsible for the development of rural Bidayuh community empowerment and types of empowerment that have resulted in the Bidayuh rural community. This study uses the phenomenological research paradigm that focuses on understanding and narrations of the Bidayuh smallholders' rural community in the District of Serian, Sarawak on how their empowerment were resulted. The sample was selected using the non-probability sampling that is the purposive sampling and the snowball sampling. A total of 16 informants were selected in this study to be interviewed in-depth. The study found that the role of MPOB consists of information sharing on oil palm cultivation, technical assistance, advisory services and expertise, providing assistance with seeds, fertilizers and pesticides as well as marketing. The type of empowerment that has been built consists of the individual empowerment, technical, communication and marketing of the oil palm products. In conclusion, MPOB is only instrumental as an agent in the Bidayuh community empowerment in a structure, and this structure is controlled by the agency through a top-down approach.

Keywords: Empowerment, community development, Bidayuh ethnic, smallholders

\section{Introduction}

The main issue to be given focus in this study is the role played by MPOB in empowering the Bidayuh community as smallholders in the cultivation of oil palm. The main question that often arises in the discussions on community empowerment is whether the empowerment is formed by the agency in the structure or whether it exists naturally within the community without assistance from the agency. This question is in line with comments by Giddens (1991), stating that the relationship between agency and structure is dependent on the goals and interests of both parties as agency and structure are having different knowledge, needs, desires and goals. The role of MPOB that is intended to be highlighted in this study includes various aspects, among others are the financial assistance, guidance, advice, injection of knowledge and information sharing that may be among the main issues in the Bidayuh community in Serian District who have just started the cultivation of oil palm activities. The issue of empowerment to be examined in this study is the extent of the program and assistance provided by MPOB had empowered the rural Bidayuh community smallholders in terms of 
attitude, relationships, knowledge, communication skills, leadership, management, marketing, technical and thoughts. Most of the previous studies stated that the types of rural individuals' empowerment can be divided into four main types that is external strength or their appearance, internal empowerment involving spiritual strength, empowerment to improve the individual capacity development and lastly, the collective strength whereby individuals have the power to determine their own directions in achieving the goals set by their needs and desires (Hoque and Itohara, 2009; Rahman and Naoroze, 2007; Chegini, 2010). Accordingly, this study also examines the form of assistance provided or distributed by MPOB to the Bidayuh community either in the form of material and non-material. Input provided by MPOB will determine to what extent does the type of empowerment resulted is in line with the results of the previous studies on empowerment.

\section{Literature Review}

\subsection{The concept of empowerment in the community development programme}

The empowerment concept is derived from the word power, autonomy and freedom (Burns, 2004; Friedmann, 1992; Touwen, 1996; Chegini, 2010). Empowerment is seen as a growing power and authority for better action towards those who are weak or poor (Asnarulkhadi and Fariborz, 2010; Lyndon et al. 2011). The concept of empowerment focuses on the potential possess by every individual which has the ability for better self-improvement (Chegini, 2010; Asnarulkhadi and Fariborz, 2009). Empowerment exists in human as an external impetus for self-improvement through the potentials possess (Hoque and Itohara, 2009; Rahim \& Asnarulkhadi, 2012). The communities' empowerment is seen as an intention to raise the dignity of the society which previously was weak or incapable to a better stage to free themselves from poverty and backwardness whereby empowerment is aimed at making people feel more self-reliant (Lely, 2013; Kelly Vlaenderen. Based on the study conducted by Kalsom \& Nor Ashikin, 2005 stated that empowerment means capacity expansions or efforts seen as playing dual roles as a motivation for the people to be involved and also as a result of their participation. Empowerment will be effective after the existence of participations among the target communities in the program organized by the administration in which effective participations will only happen after the people are empowered through trainings, information sharing and discussions (Burns, 2004; Lavers, 2008; Craig Mayo, 1995). Previous researches have categorized empowerment into four types, namely the economic empowerment, social empowerment, political empowerment and psychological empowerment (Naoroze Rahman, 2007; Lavers, 2008; Burns, 2004).

There are sociologists who stated that empowerment refers to an autonomy and an individual freedom in making decisions, not autarchy in nature and is a social experience based learning (Friedmann, 1992; Touwen, 1996). Touwen (1996) stated that there is a difference between individual and community empowerment as communities and individuals have different wants and needs. This is because individual focuses on the socioeconomic aspects of family and the community give more emphasis on the collective aspect of autonomy involving political and cultural aspects that would eventually form organizations and social pact (Touwen, 1996; Scottish. 2009). These opinions clearly show that empowerment is a process of change focusing on expanding the range of individuals' or communities' choices in decision-making. Therefore, empowerment should not be understood as a single dimension in view of changes either as a process or outcome of the process. Contrary, it must be understood in a particular context, taking into consideration the specific need of individuals to be empowered and the extent of the individual's autonomy or independence in decision making (Scottish, 2009; Kasmel and Anderson, 2011; Lyndon et al. 2012).

\subsection{Description of Malaysian Oil Palm Board (MPOB) in brief}

Malaysian Palm Oil Board (MPOB) is a key government agency responsible for providing services in the national oil palm industry. The key role played by MPOB is to promote and develop national objectives, policies and priorities for the wellbeing of the Malaysian palm oil industry. Malaysian Palm Oil Board (MPOB) was incorporated under an Act of Parliament (Act 582) and established on May 1, 2000, acquired through the merger of the Palm Oil Research Institute of Malaysia (PORIM) with the Palm Oil Registration and Licensing Authority (PORLA) which initially, PORIM was established in 1979 under the Ministry of Primary Industries Malaysia to design and conduct research related to oil palm. PORLA is involved in the marketing efforts and oil palm control. These prominent organizations have been involved in the oil palm industry for over 20 years and have provided effective services and given more focus on the industry either nationally or internationally causing the establishment of MPOB. MPOB obtained its main fund from payments of the processes that is imposed on the industry for every tonne of oil palm and oil palm kernel produced. Additionally, MPOB also received a budget allocation from the government to finance the development and research projects that have been 
approved under the Intensification of Research in Priority Areas (IRPA) programme.

\section{Research Methodology}

This study uses the abductive research strategy based on the idealist ontology and constructionist epistemology. Under the abductive research strategy, sociologists should use the same skills as the social actors to understand the reality of the issues to be studied. This coincided with the comments given by Blaikie (2000) stating that the research on perceptions or opinions must begin by describing the activities of the actors and the social significance, and rise from there the categories and concepts that can be used as a basis of understanding or explaining the key issues to be understood. In this case, the qualitative approach has been used as the main data collection method. A total of 16 Bidayuh community smallholders of the Tebedu Mawang, Mujat and Mentu villages in Serian District were selected for the in-depth interviews and focus group discussions (Map 1). The three villages have been chosen because they have the most number of full-time smallholders compared to other villages.

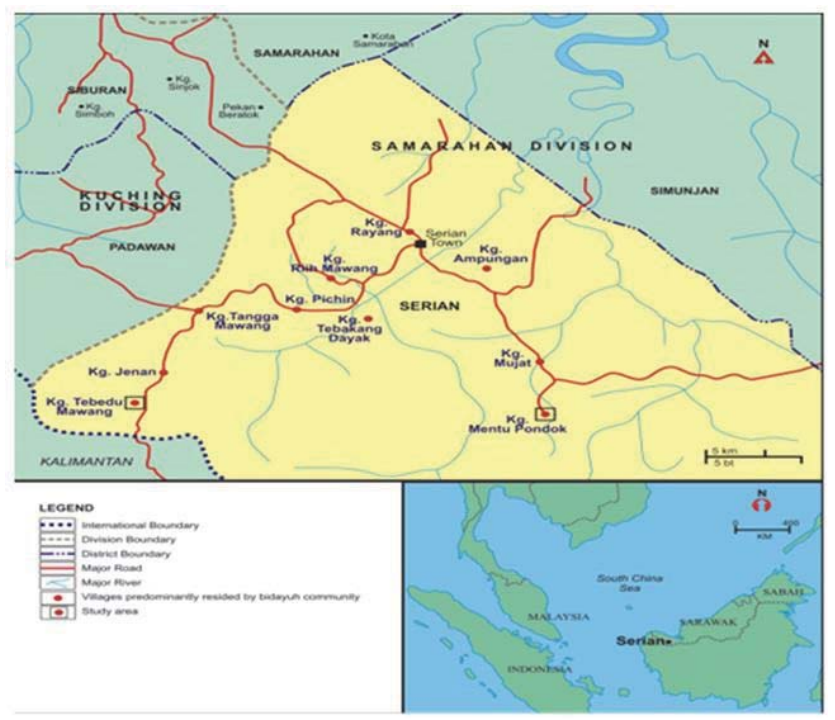

Map 1: Map showing the Research locations

Resource: District Office of Serian, Sarawak

These informants are the recipient of MPOB assistance programmes and are working full-time on their oil palm plantations. The questions guideline was constructed to assist the interviews so that it will not deviate from achieving the study objectives. The non-probability sampling technique consists of sampling has been chosen. The sample size is achieved through the continued support of the measure or criterion of the data saturation. Data were collected through the in-depth interviews and focus group discussions with informants during a period of six months by focusing on the forms of assistance provided or distributed by MPOB and the types of resulted empowerment when they act as the participants in programmes organized by MPOB in the form of material or non-material. All the transcript were translated from the Bidayuh language to Bahasa Melayu. Each transcript was later revised repeatedly to maintain the authenticity of the data and analysed in verbatim in which a matrix table was produced to facilitate the process. All the data that have been compiled were then analysed and managed using NVivo software to generate themes.

\section{Results and Discussion}

\subsection{MPOB's role in empowering the rural Bidayuh community smallholders}

The Malaysian Palm Oil Board (MPOB) vision is to be a research institution and the premier class Nobel Laureate 
research, providing leadership and encouragement for the development of the oil palm industry that covers a wide range of products, high value-added, globally competitive and sustainable. MPOB's mission in the oil palm industry is to drive the prosperity of Malaysian oil palm industry through research, development and excellent services. In ensuring that the oil palm industry in this country continues to progress and experience better improvements, MPOB has several strategies in place, among others are expanding and increasing the use of oil palm products, find new usage of oil palm, improve production efficiency and product quality, optimizing land use in the area of oil palm plantations and encourages the usage and marketability of oil palm products.

MPOB has responsibilities or functions that have been entrusted by the government. Among MPOB's contributions to the oil palm industry in Malaysia is implementing the policy and program development to ensure the viability of the oil palm industry in Malaysia continues to be enhanced; guiding and encouraging research and development activities related to the oil palm industry; regulate, register, coordinate and promote all activities related to the oil palm industry; develop, promote and commercialize research and provides technical, advisory and consultancy to the oil palm industry; develop and maintain markets for oil palm products and also to promote efficiency in the market; development of the oil palm industry in Malaysia; designing and implementing training programs and human resource development in accordance with the current requirements of the oil palm industry; as well as a resource and information centre for the oil palm industry, including the publication and dissemination of information on oil palm and other oils and fats.

\subsection{Types of empowerment of the rural Bidayuh community smallholders}

Participation by the Bidayuh community of Serian district in the oil palm cultivation activities has created empowerment to the community. Empowerment is a social action that encourages the participation of communities and organizations to achieve the goal of improving individual's and community's control, political efficacy, improved the quality of community life and social justice (Burns el al.2004; Vlaenderen Kelly, 1995). Empowerment is very important in determining the success of the community's participation (Asnarulkhadi \& Fariborz, 2010; Friedmann, 1992). The level of empowerment is related to the level of participation by the community as well as the power in decision making. This shows that empowerment is the result of participation (Touwen, 1996; Friedmann, 1992). The empowerment aspect experienced by the communities involved in the development programmes can be categorized into several parts involving the psychological, economic, political and social aspects (Kalsom \& Nor Ashikin, 2006; Haslina \& Regina, 2009; Touwen, 1996). According to the analysis results of a study conducted by the researchers, there are some similarities with the results of the previous studies, however, there are some differences in the results obtained involving the type of empowerment among the Bidayuh community in Serian district who are involve in the oil palm cultivation.

\subsubsection{Individual empowerment}

The informants' participation in the oil palm cultivation activities has led to the existence of two types of empowerment that is the internal and external empowerment. The internal empowerment involves only self-empowerment or selfconfidence of each individual involved. The same aspects were described in the previous studies involving psychological empowerment issues having in common the results obtained by the researchers but in different terms (Scottish, 2009; Kasmel and Anderson, 2011; Lavers, 2008). Psychological empowerment happened when the level of self-confidence of the community participating in the development projects increases which causes them to strive to improve the knowledge as well as seeking for training opportunities. The individual empowerment experienced by the informants is selfconfidence. High self-confidence that exists in the community participating in the development programs will give them the freedom to choose and act for which it is due to their desire for change (Hoque \& Ithora, 2009; Touwen, 1996). The informants who carried out the oil palm cultivation has changed in terms of increased self-confidence. It is due to them having to deal with MPOB to get help and information aimed at improving their knowledge in care of the crops and cultivation methods. The self-confidence occur as a result of the existence of power to demand their rights. This power gave the community freedom to choose and act based on the desire for change (Eyben et al., 2008).

Majority of the informants stated that they have never been dealing with the administration before they carry out the oil palm cultivation and even before this, they do not have any information concerning MPOB and its role. There are informants entrusted by their colleague to become the representative to deal with matters involving MPOB as an official correspondence, obtaining application forms to make licenses, aid schemes and to participate in courses organized by MPOB. This is confirmed by informants R2, R7, R8, R9 and R10 who prior to this have never been involved in any dealings with MPOB but after involving themselves in the oil palm cultivation, they deal a lot with MPOB, among others are the applications for licenses, attending courses organized by MPOB in Serian community hall and application for oil 
palm seedlings assistance scheme, fertilizer subsidies and funding to make pathways to the palm groves whereby these businesses is done solely by informants R10 from the Mentu Pondok village. The oil palm planters need to deal with MPOB because they have to make licenses to enable them to sell the yields. There are also matters involving the Bidayuh community and MPOB when they need to obtain information regarding methods of care and oil palm cultivation and getting fertilizers and pesticides assistance schemes. It has increased the Bidayuh community's self-confidence and erodes the feelings of shame in dealing with the administration.

To cultivate the oil palm, the informants or the Bidayuh community of Serian district requires a high level of selfconfidence. This is due to the requirements to meet or deal with MPOB officers in getting advice and financial assistance. In addition, they need a high level of self-confidence to deal with matters pertaining to changing of agricultural pattern that was previously involved with traditional crops such as padi and pepper, traditional crop management systems is very much different from the commodity crops. The oil palm cultivation requires knowledge regarding the crops, cultivation methods, managing the crops and the financial management knowledge on capital cycle, salaries of the employees, tools, transportation and others. Oil palm cultivation does not only increases the income of informants and the Bidayuh community in Serian district who are involved in the oil palm cultivation but also changed the inherited traditional crops management system to a more systematic management by creating the social mobility or social change in the Bidayuh community.

\subsubsection{Technical Empowerment}

In addition to the internal empowerment involving the individual's empowerment, is the self-confidence by engaging themselves in the development program, dealing with the administration and dare to make changes outside of the traditional Bidayuh community cultivation, external empowerment from the technical aspects or involving skills has changed the quality of life of the Bidayuh community who runs the cultivation of oil palm in Serian District. Through courses and meetings held by MPOB in introducing and providing information on oil palm cultivation to the Bidayuh community has added the information and improve their skills. The technical skills possess by the informants as a result of information sharing either from the MPOB or friends has helped in empowering the informants. The information obtained is used in the cultivation of oil palm and increasing the standard of living, increased their self-confidence in making decisions and change the mindset of farmers who undertake the cultivation of oil palm that they are more commercially oriented and open to change for their wellbeing, managing the oil palm plantation with confidence.

Technical empowerment experienced by the informants through information sharing directly from MPOB and friends has increased the knowledge of the informants regarding oil palm cultivation and were used to change their standard of living. Effective participation can occur after the community is empowered through training, information sharing and discussion (Scottish, 2009; Kasmel and Anderson, 2011) in which the sharing of information provided by MPOB through lectures and courses held is the given technical empowerment. Majority of the informants get basic information regarding oil palm cultivation, method of planting and managing the plantation from MPOB, but there are also informants who received information from the experience of working with SALCRA (Land Consolidation and Rehabilitation Authority Sarawak) and sharing of information from colleagues who had worked with SALCRA. This was stated by informants R2, R3, R6, R7, R8, R9 R10.

Of the seven informants who touched on the technical empowerment, only two of them stated that they received information on methods of oil palm cultivation and management as a result of earlier information sharing from friends who run oil palm plantations, the rest said that they received information from MPOB through lectures and courses organized. Fundamental and technical information pertaining to the oil palm and methods of cultivation received by the informants were not only applied to improve the economic status of the Bidayuh rural community families, but also serve as a tool to increase the capacity for self-development and self-confidence. According to informants, R2, R3, R6, R7 and R8 they obtained basic information pertaining to the oil palm cultivation through lectures or meetings organized by MPOB held at the respective village community halls. In the lectures or meetings held, MPOB officers will provide information on the type of soil suitable for cultivation of this commodity, the produce, seeds, methods of pesticides usage and fertilizers as well as companies recommended to get seeds and the farming basic needs.

\subsubsection{Communication Empowerment}

In addition to experiencing the technical empowerment that has increased the knowledge and self-confidence of the Bidayuh community, communication empowerment is also experienced by the informants in this study. Based on the previous studies, the social empowerment aspect has in common with the findings obtained by the researchers but the 
social empowerment stated in the previous studies are too general. The previous studies shows that the social empowerment is an empowerment involving unity and a closer relationship in the community following the cooperation of the local people in ensuring the success of the ongoing development and part of the revenue is used for the community development (Haslina \& Regina, 2009, Lely, 2013 ). Results of the study revealed that communication empowerment exists among the informants who undertake the planting of oil palm due to their need to communicate with the external or third-party administrator to obtain information regarding the plant or the assistance provided by MPOB. They can also connect with individuals who have been engaged in oil palm cultivation to obtain advice and recommendations pertaining to supplies that can be obtained for fertilizers, pesticides, tools and oil palm seeds. The relationships through communication that exists between the smallholders and the administrators, the suppliers or the local community is increasing the empowerment of the farmers to remain planting the oil palm even if they have to deal with various problems.

The relationship that exists among the smallholders and MPOB has helped them to easily obtain information, advice and assistance which are much needed by the Bidayuh community farmers whereby the oil palm cultivation is still new and requires a relatively big capital. This has directly assist the Bidayuh community in improving their selfconfidence, knowledge and economic status that have an impact on improving their quality of lives. Communication empowerment happens after the informants or the oil palm growers try to get assistance and information from MPOB or individuals who has run the oil palm plantations. This has facilitate them to run the oil palm planting activities, manage the plantations and finance. It also helps farmers in creating a good social network which directly assist them in marketing their oil palm produce more easily. It is experienced by some informants who have good relationships with the administrator and good social networks with various parties and individuals, this has become a stepping stone for them to obtain supplies, information as well as to easily market their produce. Informants R2, R6, R8, R9 and R10 are those who have experienced the communication empowerment through the relationship that exists either with MPOB, other individuals who have been cultivating the oil palm as well as companies that supply goods and equipment's for the needs of oil palm cultivation.

Informant R2:

\begin{abstract}
"....... Information on the cultivation method I received as a result of being employed by SALCRA and guidance from my husband. My husband obtain information regarding oil palm cultivation methods because he has participated in seminars and courses organized by MPOB in providing information on oil palm, methods of care and others. My husband also participated in meetings organized upon completion of the course participated. Having experience with MPOB has resulted in my husband being considered for by some of his friends to become the leader in dealing with group applications for assistance given by MPOB. At the same time, my husband obtained additional information regarding the oil palm from his friend who works at the Department of Agriculture on the types of fertilizers, pesticides and cultivation methods in more detail. "
\end{abstract}

The same thing was experienced by informants R6 of Kampung Tebedu Tegayang who received information on the methods of oil palm seeds planting, the distance between each sapling, methods of managing the palm groves, poisoning the grass and clearing are information obtained after joining the lectures conducted by MPOB. At the same time, communication or relationship exists between the informant and MPOB when applying for oil palm seeds assistance. The informant and her husband also apply for assistance from the New Planting Scheme from MPOB prior to cultivating of the oil palm but yet to receive any feedback. However, communication empowerment happened after the informant and her husband became interested in planting oil palm by attending lectures organized and assistance applications.

\title{
4.2.4 Market Empowerment
}

The informants interviewed by the researchers are also experiencing empowerment in the marketing aspect. To the informants who have obtained the revenue from the oil palm cultivation, they will definitely choose a company or manufacturer that offers a satisfactory price. This affects the amount of revenue that would be raised by the informants. Before allowing informants to market their oil palm produce, the informant must first have the license issued and approved by MPOB. There are several informants who choose to market their produce to the private companies, but they are those who sell the crops to the factories responsible for processing the crop. Informants R8, R9 and R10 are among several informants who experienced the marketing empowerment for which they have been engaged in the oil palm cultivation for more than four years, the crops has produced results and they have sold their produce to the reliable agencies or factories. 
Informants $R 8$ "Revenue is only obtained once a month. Oil palm planting is easier compared to planting pepper because it is easier to collect the produce even if the fruits have fallen to the ground. I sell the oil palm produce to SALCRA. At first, I only get a yield of $500 \mathrm{~kg}$, but now the amount is increasing to more than 2 tons especially during heavy fruit season, if not, just get $800 \mathrm{~kg}$ to 1 ton."

The informants or the oil palm farmers do not only need the technical information in the planting and care of plants as well as good communication relationship between smallholders with government agencies for advice and assistance, but they also need to make careful planning in terms of managing oil palm revenues and marketing. R8 informant sells the oil palm produce once a month to SALCRA and it was transported by a lorry rent from a friend. The informant choose to sell the oil palm produce to SALCRA due to much information on the care and planting of oil palm resulting from their spouses or friends experiences working with SALCRA. Besides that, the price offered by SALCRA is stable as compared to other private companies which are very profit oriented. The same goes to informant R9 and R10 who came from the Mentu Pondok Village and Mujat village that they too choose to sell their oil palm produce to SALCRA. According to R9 informant, he has been planting oil palm for three and a half years and has yielded the produce five times which were sold to SALCRA.

\section{Conclusion}

MPOB only plays the role as an agent in empowering the rural Bidayuh community in a structure and this structure is controlled by an agency through the top-down approach. This is not a new strategy to the development organizations or agencies that are trying to empower a person or an individual without knowing the type of empowerment already existing in the person or individual and whether or not the input given is according to the person's or individual's need. However, the basic matter that needed to be addressed between the agency and the structure is that an individual or a community cannot be empowered from outside. The individual or community can only be empowered by themselves and the combination between the agency and structure. The role of the agency and organization is just as a facilitator in the structure assisting in giving inputs, space, creating situations, eliminate obstacles and encourage the individuals empowering efforts internally through the participation process between structure and agency. This is in line with the comment by Touwen (1996) and Lavers (2008) stating that the individual empowerment is not an absolute empowerment because it was built as a result of an ideal construct combination between the agency and community. The local community construct and the agency's scientific construct should be combined to produce a construct that represent both parties. Based on the discussions, the type of the rural Bidayuh community empowerment can be fundamentally divided into two main types that is: the existing empowerment or natural empowerment possess by the smallholders and the empowerment created and naturalized between the structure and agency.

\section{Acknowledgement}

This research is supported by the MPOB-UKM Endowmen Chair under the MPOB-UKM Grant-2013-004 that enabled the research to be successfully conducted.

\section{References}

Asnarulkhadi A.S \& Fariborz Aref. (2010). The theoretical and conceptual framework and application of community empowerment and participation in processes of community development in Malaysia. Journal of American Science, 2011; 7(2)

Asnarulkhadi A.S \& Fariborz Aref. (2009). Empowerment as an approach for community development in Malaysia. World Rural Observation 1(2): 63-68

Asnarulkhadi A.S \& Fariborz Aref. (2009). People's participation in community development: a case study in a planned village settlement in Malaysia. World Rural Observation 1(2): 45-54

Blaikie, N. 2000. Designing Social Research: The Logic of Anticipation. Cambridge: Polity Press.

Burns, Danny et al. (2004). Making Community Participation Meaningful: A Handbook for Development and Assessment. UK: The Policy Press.

Chegini M.G. (2010). Study of relation of psychological factors of empowerment and Entrepreneurship. American Journal of Economic Business Administration 2, 86-89. DOI:10.3844/ajebasp.2010.86.89.

Craig Gary \& Mayo Marjorie. (1995). Community Empowerment. United Kingdom. London. Zed Books Ltd.

Eyben, Rosalind et al. (2008). Conceptualising Empowerment and the Implications for Pro Poor Growth. Institute of Development Studies.

Friedmann, J. (1992). Empowerment. The politics of an alternative development. Oxford: Basil Blackwell. 
Giddens, A. (1991). Modernity and self-identity. Self and society in the late modern age. Cambridge. Polity Press.

Haslina Hashim \& Regina Garai Abdullah. (2009). Penglibatan Komuniti dalam Program Pembangunan Luar Bandar: Kajian Kes di Pusat Pertumbuhan Desa Gedong, Sarawak. Bangi: Universiti Kebangsaan Malaysia.

Hoque M, Itohara Y. (2009). Women empowerment through participation in micro-credit programme: A case study from Bangladesh. J. Soc. Sci. 5, 244-250. DOI: 10.3844/jssp.2009.244.250.

Kalsom Kayat \& Nor Ashikin Mohd. Nor. (2006). Penglibatan Ahli Komuniti dalam Program Pembangunan Komuniti: Satu Kajian Ke Atas Program Homestay di Kedah. Bangi: Penerbit Universiti Kebangsaan Malaysia.

Kasmel Anu \& Anderson Pernille Tanggard. (2011). Measurement of community empowerment in three community programs in Rapla (Estonia). International Journal of Environment Research and Public Health, 8, 799-817.

Kelly, K. \& Vlaenderen .(1995). Evaluating Participation Process in Community Development. Rhodes University.

Lavers T. (2008). Reconciling the needs and wants of respondents in two rural Ethiopian communities. Soc. Indicators Res. 86, 129-147. DOI: 10.1007/s11205-007-9110-x

Lely I. M. (2013). Pemerkasaan Wanita Pekerja Rumah Tangga (PKT) Indonesia: Kajian di Lembah Klang. Bangi: Universiti Kebangsaan Malaysia.

Lyndon. N., Moorthy. R., ER. A. C \& Selvadurai S. (2011). Native understanding of participation and empowerment in community development. Journal of Social Science 7(4): 643-648

Lyndon. N., Er. A. C., Selvadurai. S,. Mohd. Fuad. M. J., Mohd Yusof Hussain \& Junaidi. A.B. (2012). Bidayuh world view on participation and empowerment in community development. Advances in Natural and Applied Sciences 6(1): 10-18

Rahman HM \& Naoroze K. (2007). Women empowerment through participation in aquaculture: Experience of a large-scale technology demonstration project in Bangladesh. J. Soc. Sci. 3, 164-171. DOI: 10.3844/jssp.2007.164.171.

Touwen, A. (1996). Gender and development in Zambia. Empowerment of women through local non-governmental organisations. University of Groningen, Eburon Publisher

Rahim. M. S \& Asnarulhadi Abu Samah. (2012). Community development through community capacity building: a social science perspective. Journal of American Science 2010:6 (2): 68-76

Scottish A. (2009). Community Scottish Community Empowerment Action Plan Celebrating Success: Inspiring Change. Edinburgh. Scottish 